\title{
Pengembangan Sistem Database Terpadu Berbasis Web Untuk Penyediaan Layanan Informasi Website Desa
}

\author{
Mansur1,* , Kasmawi2 \\ 1,2Dosen Teknik Informatika Politeknik Negeri Bengkalis \\ (corresponding author) mansur@polbeng.ac.id*; kasmawi@polbeng.ac.id
}

\begin{abstract}
Village Information Service is a very important role in creating transparency of village information to be conveyed to the public at large. It is closely related to data storage medium called a database. Bengkalis district government strongly encourages each village to have a web page that serves as a media in conveying information to the wider community as well as be able to submit a program of activities and the realization of the budget environment of the village administration. Moreover, the existence of the village website can also be used to promote the potential of every village widely. For that, it needs the development of integrated web-based database system for the provision of information services of the village. The database is built based on the design of database conceptual, logical and physical by taking into account the criteria in the design database. The database design is continued with the creation of websites village as an integrated database testing, in this case the data is used as an example is data sungai alam villages and rural districts meskom bengkalis. Integrated database system is able to accommodate more than one village data in a database so that it can make recommendations to the district to collect data from every rural village and data storage can be performed optimally.
\end{abstract}

Keywords-Desain system, database integrated development, village information service

Intisari-Layanan informasi desa sangat berperan penting dalam menciptakan transparansi informasi desa untuk disampaikan kepada masyarakat secara luas. Hal tersebut erat kaitannya dengan media penyimpanan data yang disebut dengan database. pemerintah Kabupaten Bengkalis sangat mendorong setiap desa untuk memiliki halaman website yang berfungsi sebagai media dalam menyampaikan informasi kepada masyarakat secara luas serta dapat dapat menyampaikan program kegiatan maupun realisasi penggunaan anggaran dilingkungan pemerintahan desa. Selain itu, keberadaan website desa juga dapat dimanfaatkan untuk mempromosikan potensi yang dimiliki oleh setiap desa secara luas. Untuk itu, perlu pengembangan sistem database terpadu berbasis web untuk penyediaan layanan informasi desa. Database tersebut dibangun berdasarkan rancangan database konseptual, logical dan pisikal dengan memperhatikan kriteria dalam perancangan database. Perancangan database tersebut dilanjutkan dengan pembuatan website desa sebagai bentuk pengujian database terpadu, dalam hal ini data yang dijadikan contoh adalah data desa sungaialam dan desa meskom kabupaten bengkalis. Sistem database terpadu mampu menampung data desa lebih dari satu dalam satu database sehingga hal ini dapat memberikan rekomendasi bagi pihak kecamatan untuk mengumpulkan data dari setiap desa yang ada dan penyimpanan data dapat dilakukan secara optimal.

Kata Kunci-Desain Sistem, Pengembangan database terpadu, layanan informasi desa.

\section{PENDAHULUAN}

Layanan informasi desa melalui website merupakan salah satu cara bagi pemerintah desa dalam menyampaikan informasi kepada seluruh perangkat desa, masyarakat, organisasi desa dan komunitas-komunitas yang ada didesa dengan cepat dan mudah. selain itu, masyarakat juga dapat memberikan masukan kepada pemerintah desa melalui layanan informasi desa untuk pengembangan desa kearah yang lebih baik [9]. Penerapan layanan informasi sangat bermanfaat bagi pemerintah desa dalam mengumpulkan kelengkapan data dan mendokumentasikan semua dokumen dengan baik sehingga hal tersebut berdampak pada kinerja pemerintah desa untuk melayani masyarakat dengan cepat dan mudah [10]. Ada beberapa faktor yang menentukan dalam keberhasilan e-Government dalam layanan administrasi desa berbasis informasi dan teknologi (IT) yaitu Sumber Daya Manusia (SDM), Sarana dan Prasarana; Kelembagaan; Anggaran; Pelayanan IT dan Standard Layanan Administrasi Desa/Kelurahan [3]

Pemerintah Kabupaten Bengkalis mendorong setiap desa untuk memiliki halaman websiteuntuk mempermudah masyarakat dalam mengetahui secara luas program dan kegiatan, maupun realisasi anggaran dilingkungan pemerintahan desa. Selain itu, keberadaan website dapat dimanfaatkan untuk mempromosikan potensi yang dimiliki 
oleh desa. Meskipun sejauh ini belum seluruh desa di Kabupaten Bengkalis memiliki website, namun bagi desa yang sudah memiliki akses jaringan internet menjadi suatu kewajiban untuk memiliki website sebagai sarana berbagi informasi kepada masyarakat. Berdasarkan hasil survei di Kabupaten Bengkalis beberapa desa sudah memanfaatkan website sebagai media informasi dan layanan desa. Namun, secara teknologi penyimpanan data (database) masih berdiri sendiri pada masing-masing website desa. Hal tersebut dapat menimbulkan beberapa permasalahan yaitu, 1) data setiap desa tidak terintegrasi, 2) memerlukan biaya operasional cukup memadai, 3) sumber daya manusia (SDM) bidang komputer setiap desa terbatas, 4) sulitnya untuk melakukan pengumpulan data desa yang dibutuhkan oleh pemerintah tingkat kecamatan secara real time dan up-to-date [4]. Pemanfaatan database terintegrasi sangat penting untuk dikembangkan dalam pemerintahan [6]. Hal ini, berdampak pada penyajian data, informasi secara cepat dan akurat [11].

Penelitian ini bertujuan untuk pengembangan sistem database terpadu berbasis web menggunakan model prototype pada pemerintahan desa. Database terpadu tersebut dapat menghasilkan informasi profil desa, grafik monografi, dan rekomendasi bagi pemerintah daerah dalam mempermudah pengelolaan informasi desa ditingkat kecamatan.

\section{TINJAUAN PUSTAKA}

\section{A. Sistem Database Terpadu}

Sistem database terpadu (database integrated system) merupakan media penyimpanan data secara terpusat [5], yang digunakan untuk mengelola data dan informasi [2]. sistem terpadu dapat melakukan penyimpanan data secara lengkap kedalam database sehingga berdampak pada penyajian data, informasi dengan cepat dan akurat dalam mendapatkan kembali informasi tersebut. Sistem terpadu berfungsi sebagai sarana atau media penyimpanan data dan informasi yang memiliki keserderhanaan, kehandalan dan portabilitas yang tinggi. Oleh sebab itu, sistem terpadu dapat meningkatkan jaminan ketersediaan data, mendokumentasikan data pada sebuah sistem serta mempermudah pencarian informasi yang dibutuhkan oleh pengguna [11].Sistem database terpadu memiliki keunggulan yaitu [1] :

1. Integritas data lebih maksimal dan redundansi data dapat diminimalkan, sehingga data menjadi akurat dan konsisten dalam meningkatkan keandalan data.

2. Keamanan data lebih terjaga.

3. Pelestarian data akan menjadi lebih baik karena pengelola dilakukan terpusat.

4. Pengguna lebih mudah untuk mendapatkan data dan informasi karena kesederhanaan dalam desain database tunggal.

5. Portabilitas data dan administrasi database secara umum lebih mudah.

6. Efektifivas penggunaan daya listrik, sumber daya manusia dan biaya pemeliharaan sistem database dapat dioptimalkan.

7. Semua informasi dapat diakses pada saat yang sama dari lokasi yang berbeda.

\section{B. Kualitas Layanan Informasi}

Penyampaian informasi yang efektif dapat memberikan kontribusi terhadap layanan informasi yangberdampak terhadap kualitas informasi [12].Informasi yang berkualitas ditinjau dari 2 aspek yaitu efesinsi dan efektifitas dimana efesiensi dipengaruhi oleh variabel input, sedangkan efektivitas berdasarkan sistem output yang dihasilkan. Kedua aspek tersebut dapat meningkatkan kinerja sistem dalam menghasilkan informasi yang berkualitas [7]. Keterkaitan antara efesiensi dan efektifitas sistem dalam menghasilkan informasi yang berkualitas dapat dilihat pada Gambar 1. 


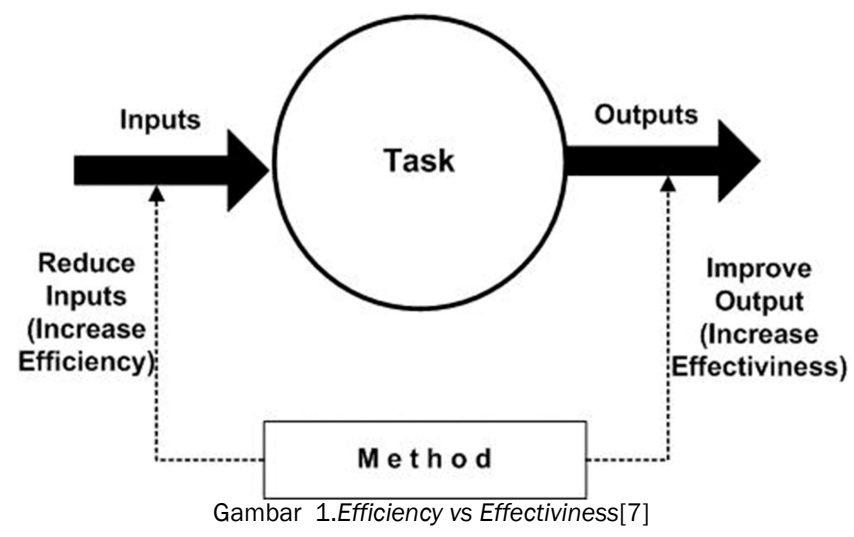

\section{Model Prototype}

Model prototypemerupakan salah satu metode pengembangan perangkat lunak dimana antara pengembangan dan pelanggan dapat saling berinteraksi selama proses pembuatan sistem. Pengembang dapat bekerja lebih baik dalam menentukan kebutuhan sedangkan pelanggan dapat mengetahui apa yang diharapkan. Hal ini, dapat menghemat waktu dalam pengembangan system dan penerapan system menjadi lebih muda. Tahapan pengembangan model prototypemeliputi mendengarkan pengguna,membangun, memperbaiki system, melakukan uji coba sistem kepada pengguna, dan melakukan pengendalian system.Model prototypemempu melakukan komunikasi yang baik antara pengembang dengan pelanggan dalam pengembangan sebuah sistem [13].Siklus pengembagan sistem menggunakan model prototype dapat dilihat pada Gambar 2 [8],[13].

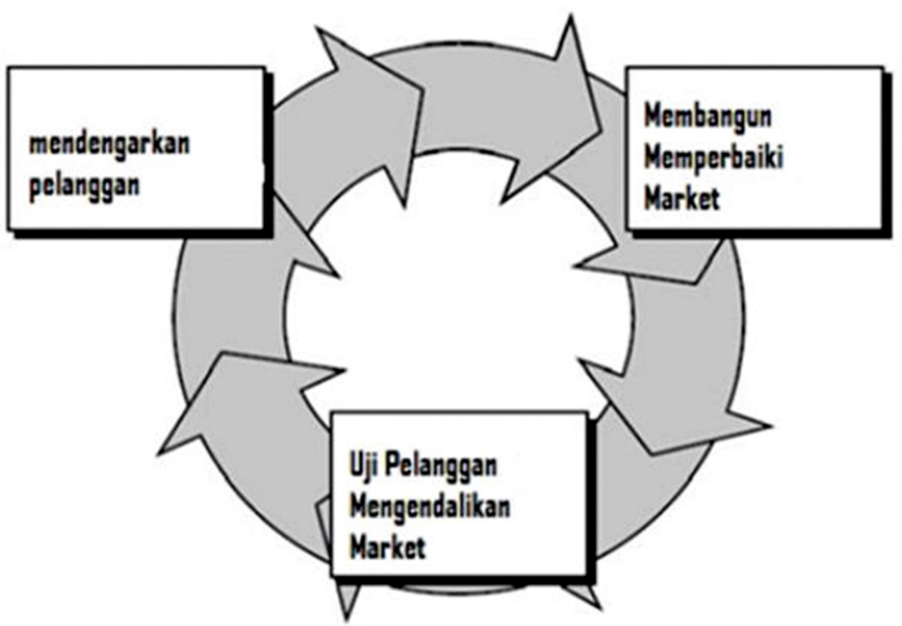

Gambar 2. Siklus Model Prototype [8],[13]

\section{METODE PENELITIAN}

Metode pengembangan sistem database terpadu menggunakan pendekatan prototype. Penelitian diawali dengan melakukan identifikasi masalah, pengumpulan data, analisa kebutuhan sistem database terpadu, desain sistem menggunakan UML, desain database, desain user interface website desa, dan melakukan pengujian. Data diambil menggunakan metode observasi, wawancaram dan studi pustaka. Metodologi penelitian dapat dilihat pada Gambar 3. 


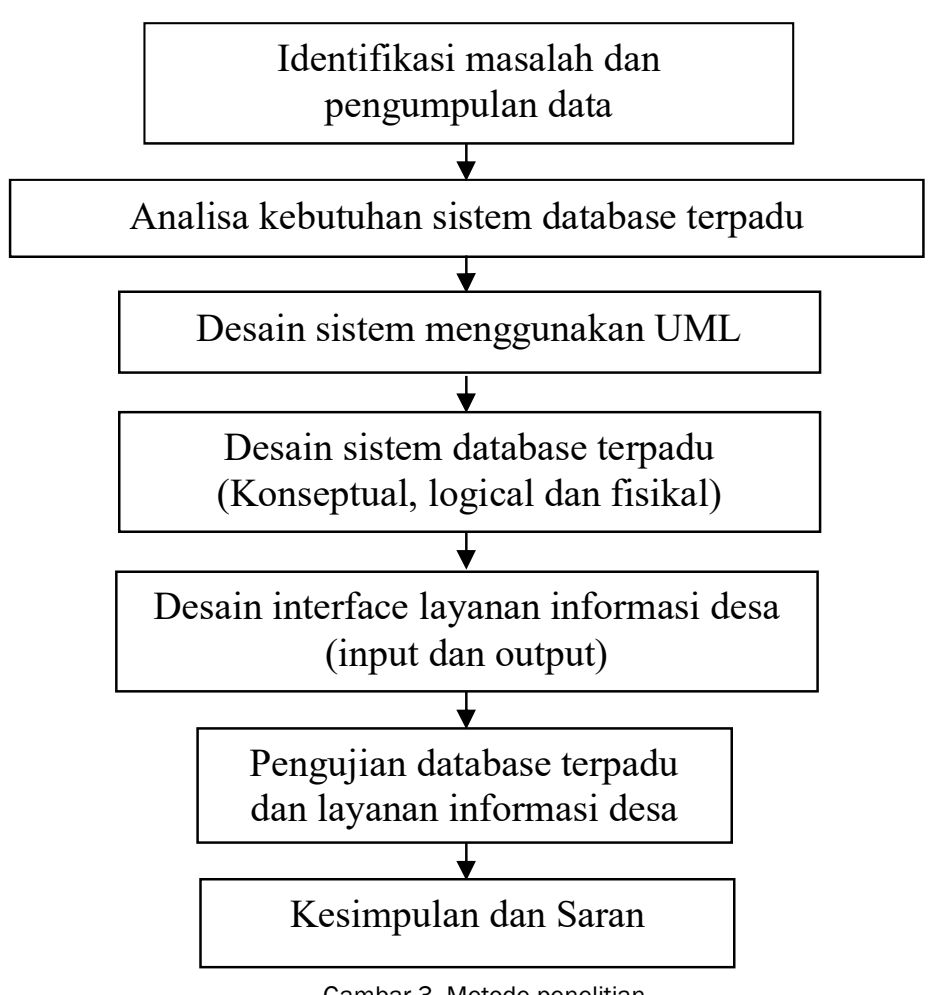

Tahapan pengambangan sistem database terpadu menggunakan pendekatanprototypeberbasis web meliputi :

1. Mendengarkan kebutuhan pengguna.

Pada tahap ini dilakukan analisa kebutuhan sistem di desa sungai alam dan desa meskom dengan cara mendengarkan kebutuhan layanan informasi yang akan disampaikan kepada masyarakat serta mengumpulkan data profil seperti data sambutan, sejarah, struktur organisasi, perangkat desa, visi misi, informasi mengenai kelembagaan (pemberdayaan masyarakat, lembaga adat, PKK, Bumdes, dan karang taruna), informasi monografi (data umum, kependudukan, sarana prasarana, kewenangan, keuangan dan data bencana), informasi peraturan, berita, daftar kegiatan, potensi, galeri, buku tamu, dan informasi kependudukan yang ditampilkan dalam bentuk grafik seperti grafik kependudukan berdasarkan jenis kelamin, usia, dan pendidikan. Data tersebut dikumpul melalui hasil observasi dan wawancara bersama kepala desa. Dimana, data tersebut sebagai acuan dalam menyusun fungsional database. Selanjutnya, data tersebut dikumpulkan untuk dapat digunakan sebagai tahap perancangan sistem.

2. Membangun dan memperbaiki sistem.

Setelah data terkumpul sesuai kebutuhan desa, maka dilanjutkan dengan membuat usulan sistem layanan informasi berbasis web dan merancang database terpadu. Database terpadu dibangun menggunakan MySQL dengan memperhatikan rancangan konseptual, logical dan fisikal. Sementara untuk pembuatan website desa menggunakan bahasa pemograman PHP. Database dan website desa yang sudah kembangkan disampaikan kepada pemerintah desa sehingga apabila terjadi perbaikan database dapat disesuaikan dengan kebutuhan fungsional database.

3. Melakukan uji coba sistem kepada pengguna, dan melakukan pengendalian sistem.

Rancangan database terpadu dan website desa yang sudah selesai dikembangkan akan diuji pada desa sungai alam dan desa meskom untuk mengetahui apakah database terpadu dan website layanan informasi desa dapat berfungsi dengan baik dan sesuai kebutuhan desa. Untuk mengoptimalkan penggunaan layanan informasi desa 
tersebut dibutuhkan admin untuk melakukan pengendalian atau monitoring terhadap database dan website desa secara berkala sehingga dapat dipastikan bahwa layanan tersebut dapat berjalan dengan maksimal.

\section{HASIL DAN PEMBAHASAN}

A. Hasil

Penelitian ini menghasilkan prototypedatabase terpadu berbasis webuntuk penyediaan informasi website desa. Prototype database terpadu dapat menghasilkan informasi layanan desa secara terpusat yaitu 1). informasi profile desa meliputi sambutan, sejarah, struktur organisasi, perangkat desa dan visi misi desa. 2) informasi mengenai kelembagaan meliputi pemberdayaan masyarakat, lembaga adat, PKK, BUMDES, karang taruna dan lembaga lain, 3) informasi monografi meliputi data umum, kependudukan, sarana dan prasarana, kewenangan, keuangan dan data bencana, dan 4) informasi direktori meliputi peraturan, berita, daftar kegiatan, potensi, galeri dan buku tamu, 5) informasi monografi dalam bentuk grafik. Selain itum sistem database dapat menampung lebih dari satu data desa yang menghasilkan layanan informasi melalui website desa. Framework sistem database terpadu dapat dilihat pada Gambar 4.

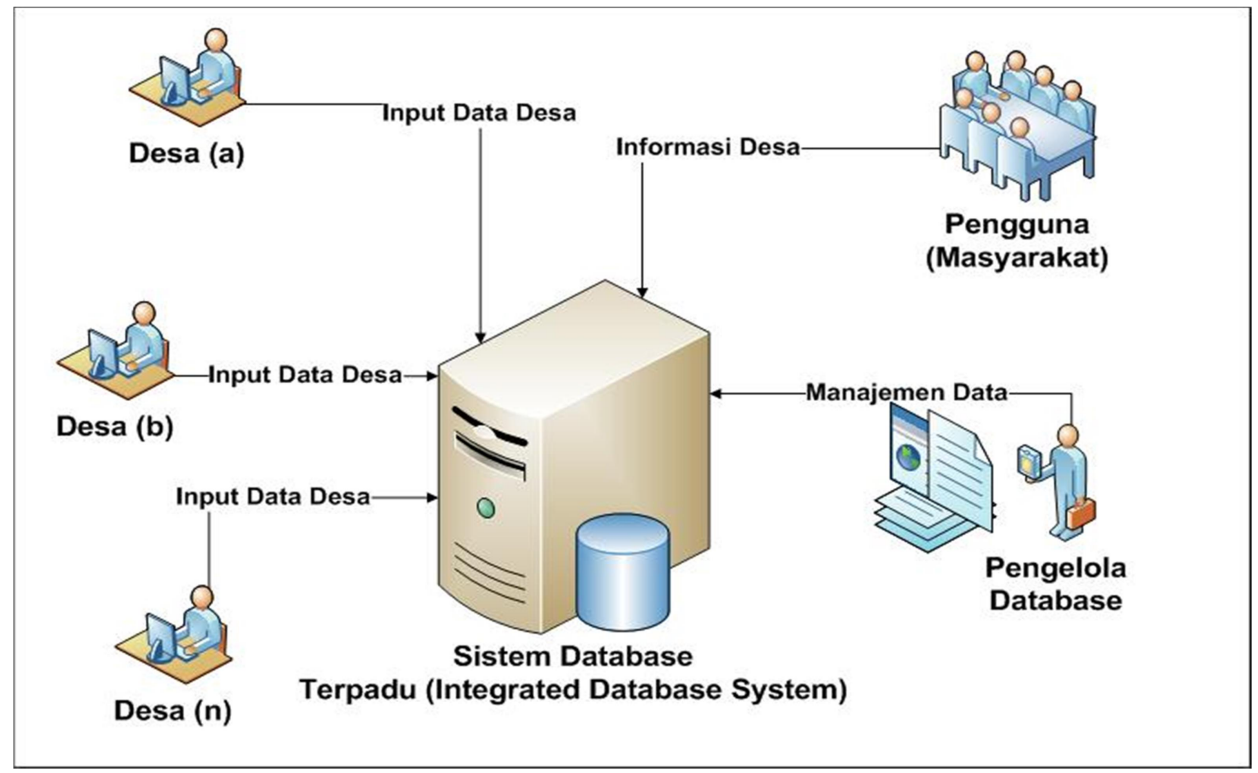

Gambar 4. Framework Sistem Database Terpadu.

B. Pembahasan

1. Kebutuhan Fungsional Sistem

Kebutuhan fungsional dalam pengembangan sistem database terpadu meliputi yaitu :

a. Sistem dapat melakukan registrasi operator desa

b. Sistem dapat melakukan login untuk kebutuhan operator desa

c. Sistem dapat melakukan setup biodata desa

d. Sistem dapat melakukan input, update, dan menghapus data profil desa

e. Sistem dapat melihat daftar buku tamu yang diinput oleh masyarakat desa dan memberikan persetujuan untuk publish terhadap informasi tersebut.

f. Sistem dapat melihat daftar poling pada setiap desa.

g. Sistem dapat memberikan informasi kepada masyarakat desa.

h. Sistem dapat memberikan kesempatan kepada masayarakat desa untuk melakukan input buku tamu yang bertujuan untuk memberikan saran dan masukan.

i. Sistem dapat memberikan kesempatan kepada masyarakat dalam mengevaluasi website melalui poling yang tersedia.

j. Sistem dapat memberikan akses penuh kepada pengelola website (Operator Desa). 
k. Sistem dapat memberikan akses kepada super admin dalam melakukan login sistem, instalasi website desa (hosting), pengelolaan database terpadu dan website desa serta dapat melihat perkembangan informasi setiap desa.

2. Use Case Diagram

Aktor yang terlibat terdiri dari tiga aktor yaitu super admin (Tim IT), Operator desa, dan masyarakat (pengunjung). Hal tersebut dapat dilihat pada Gambar 5.

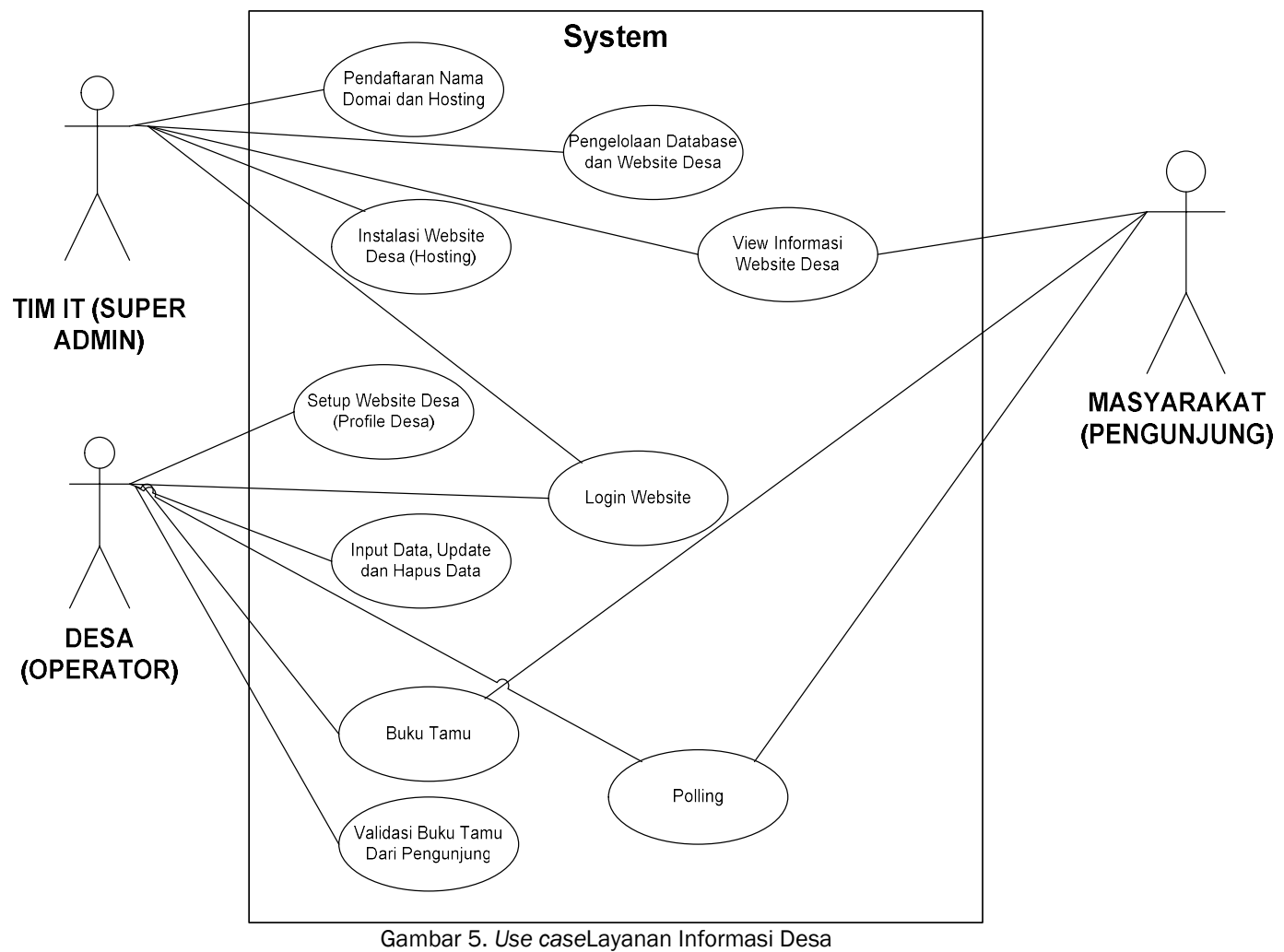

3. Arsitektur Layanan Informasi Desa

Arsitektur penyediaan layanan informasi website desa secara online terdiri dari beberapa komponen yaituuser device, process (web server, web browser, service provider and programming language) dan user desa dalam mengintegrasikan aplikasi dalam sebuah sistem. Sistem dan arsitektur pengembangan sistem database terpadu dapat dilihat pada Gambar 6. 


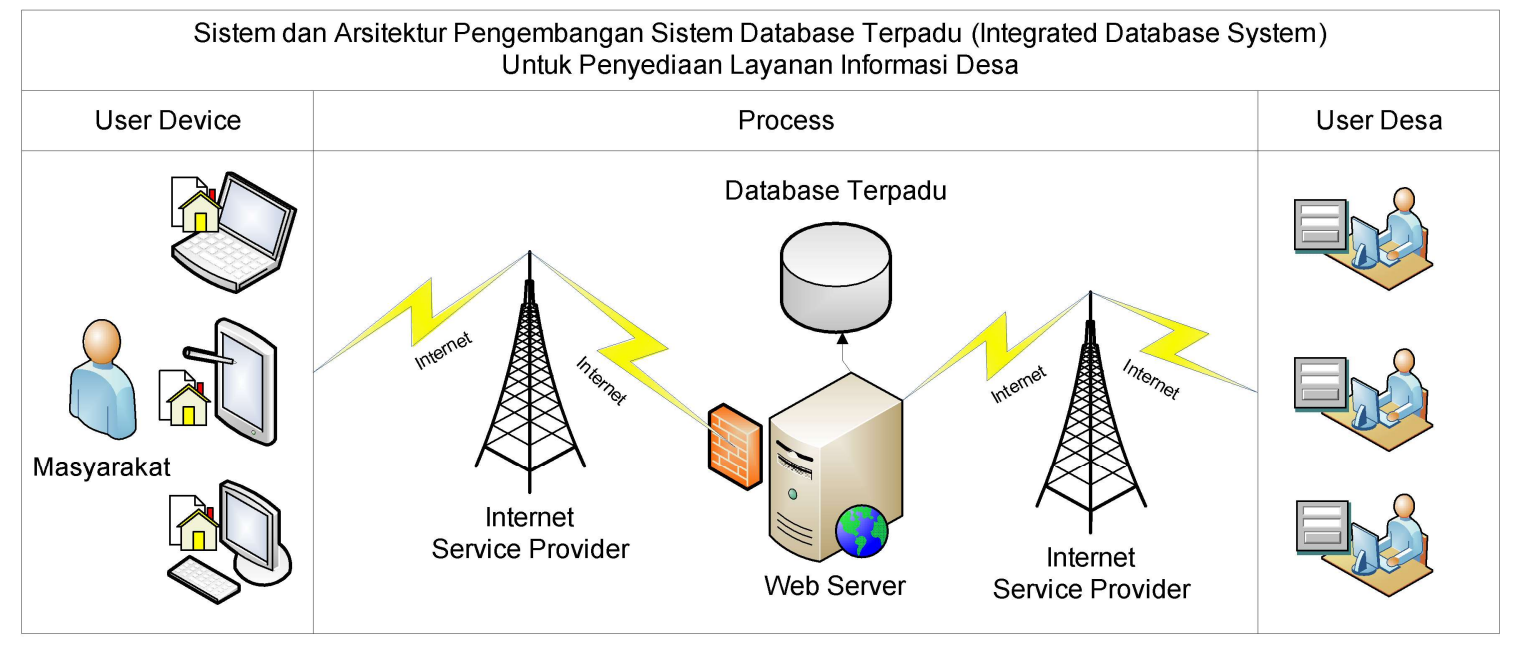

4. Perancangan Sistem Database Terpadu

Perancangan sistem database terpadu terdiri dari dari 15 tabel yang saling terlibat dalam sistem. Pengembangan sistem database terpadu dapat dilihat pada Gambar 7.

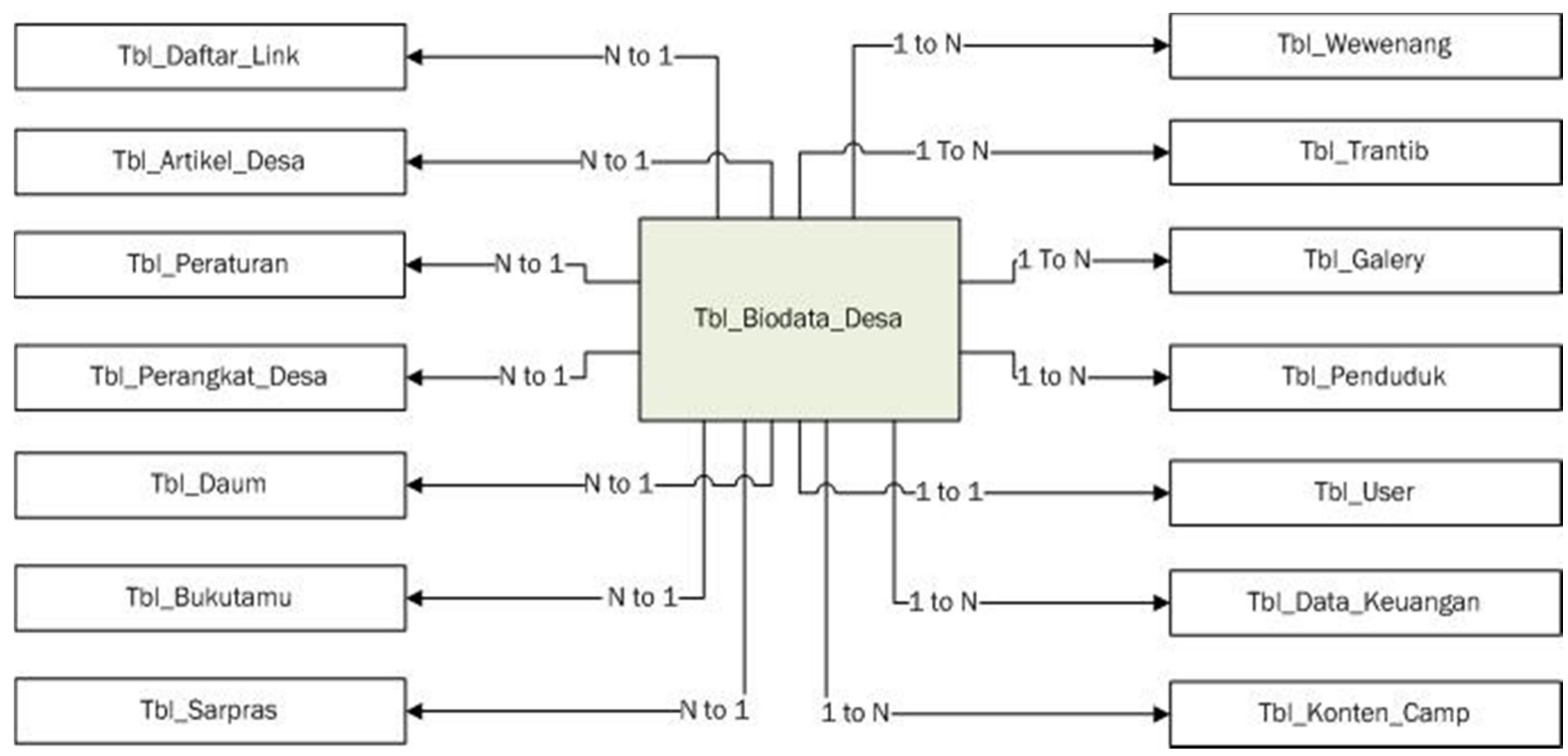

Gambar 7. Hasil desaian sistem database terpadu

Gambar 8. Menunjukkan query untuk menampilkan informasi biodata desa berdasarkan masing-masing desa

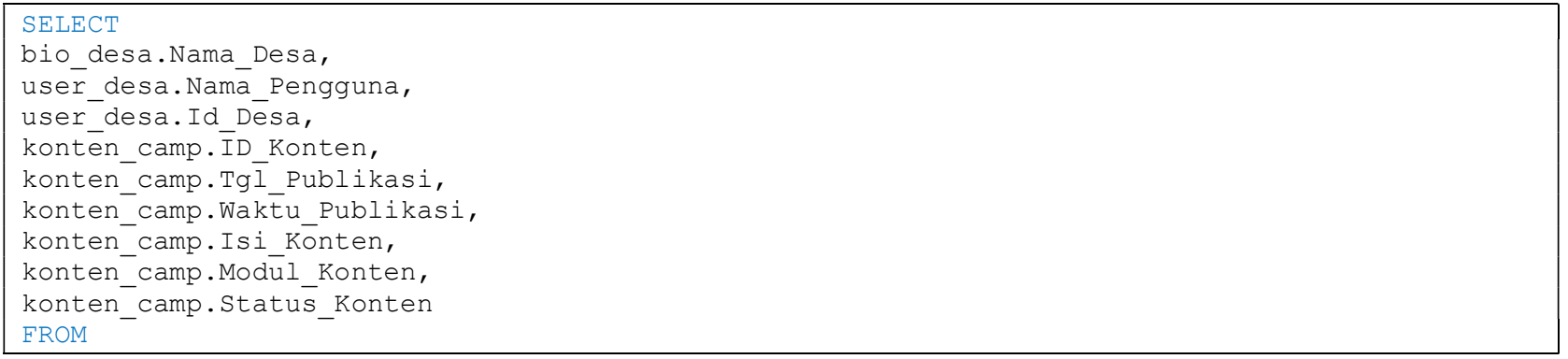




\begin{tabular}{|c|c|c|c|c|c|}
\hline \multicolumn{6}{|c|}{ r_desa ON bio_desa.ID_Desa = user_desa } \\
\hline \multicolumn{6}{|c|}{$\begin{array}{l}\text { SELECT } \\
\text { bio_desa.Nama_Desa, } \\
\text { arti_des.Kategori_Des, } \\
\text { arti_des.Judul_Des, } \\
\text { arti_des.Tgl_Des, } \\
\text { arti_des.Waktu_Des, } \\
\text { arti_des.Status_Des } \\
\text { FROMbio_desa } \\
\text { LEFTJOIN arti_desON bio_desa.ID_Desa = arti_des.ID_Desa; }\end{array}$} \\
\hline Hasil query 2 & untuk me & nampilkan kegiatan desa berdasark & ran nama desa : & & \\
\hline Nama_Desa & Kategori_Des & Judul_Des & Tgl_Des & Waktu_Des & Status_Des \\
\hline DESA SUNGAI ALAM & Kegiatan & Peringatan Hari Anak Nasional Tahun 2016 & Sabtu, 30 Juli 2016 & 10:30 AM & Publikasi \\
\hline DESA SUNGAI ALAM & Kegiatan & Acara Khitan Masal & Minggu, 31 Juli 2016 & 03:45 PM & Arsip \\
\hline DESA SUNGAI ALAM & Kegiatan & Penyuluhan HIVIAIDS Dan NAPZA & Sabtu, 06 Agustus 2016 & 03:21 AM & Publikasi \\
\hline DESA SUNGAI ALAM & Kegiatan & Pelaksanaan Apel HUT RI 17 Agustus 2016 & Rabu, 17 Agustus 2016 & 03:45 PM & Publikasi \\
\hline DESA SUNGAI ALAM & Kegiatan & Penghijauan Desa Sungai Alam & Minggu, 21 Agustus 2016 & 10:13 AM & Publikasi \\
\hline DESA SUNGAI ALAM & Kegiatan & Sosialisasi Budidaya Ikan Air Tawar & Rabu, 24 Agustus 2016 & 03:45 PM & Publikasi \\
\hline DESA SUNGAI ALAM & Kegiatan & Sosialisasi PHBS Serta Pencegahan DBD & Selasa, 30 Agustus 2016 & 10:08 AM & Publikasi \\
\hline DESA SUNGAI ALAM & Kegiatan & Pelaksanaan Pekan Muharram Dalam Rangka Menyambut ... & Kamis, 01 September 2016 & 03:45 PM & Arsip \\
\hline DESA SUNGAI ALAM & Kegiatan & Syukuran Desa & Selasa, 20 September 2016 & 04:00 PM & Arsip \\
\hline DESA SUNGAI ALAM & Kegiatan & Pembangunan Infrastruktur Jalan 2016 & Kamis, 06 Oktober 2016 & 09:45 AM & Publikasi \\
\hline DESA MESKOM & Berita & Desa Meskom Disebut Kampung Zapin & Senin, 12 Desember 2016 & 10:30 AM & Publikasi \\
\hline
\end{tabular}

Gambar 8. Query untuk menampilkan informasi biodata desa

\section{Implementasi Penyediaan Layanan Informasi Desa Secara Online}

Hasil perancangan interface untuk website desa yang tergabung dalam prototype pengembangan database terpadu dapat digunakan oleh banyak desa sebagai media penyimpanan, penyampaian data dan informasi serta promosi desa kepada masyarakat desa baik skala daerah dan nasional. Hasil tersebut dapat dilihat pada Gambar 9.

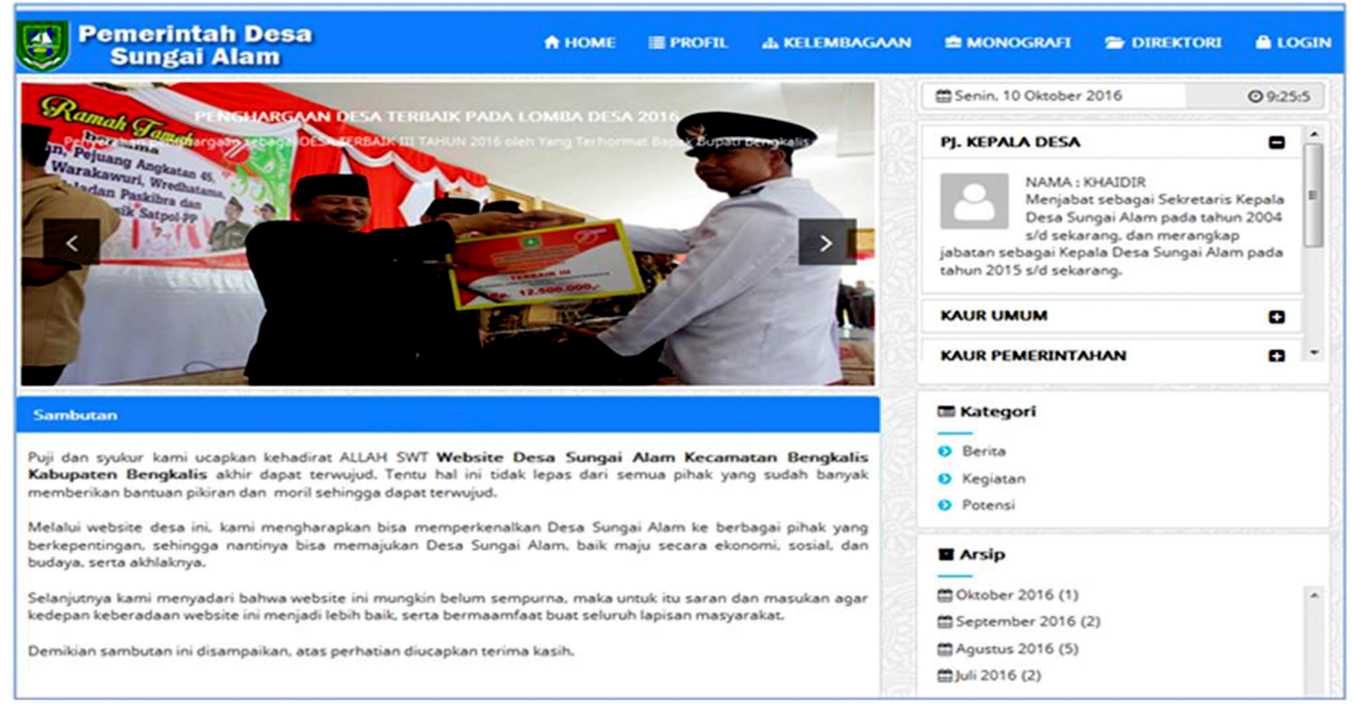

Gambar 9. Halaman utama website desa

Gambar 10. Menunjukkan menu pada halaman utama website layanan informasi desa yang terdiri dari menu home, profil, kelembagaan, monografi dan direktori. Dimana, masing-masing menu memiliki sub menu yang mempunyai fungsi yang berbeda sebagai contoh pada menu profil menampilkan sub menu tentang sambutan kepala desa, sejarah, struktur organisasi, perangkat desa dan visi misi. Begitu juga halnya dengan menu kelembagaan, monografi dan direktori. 


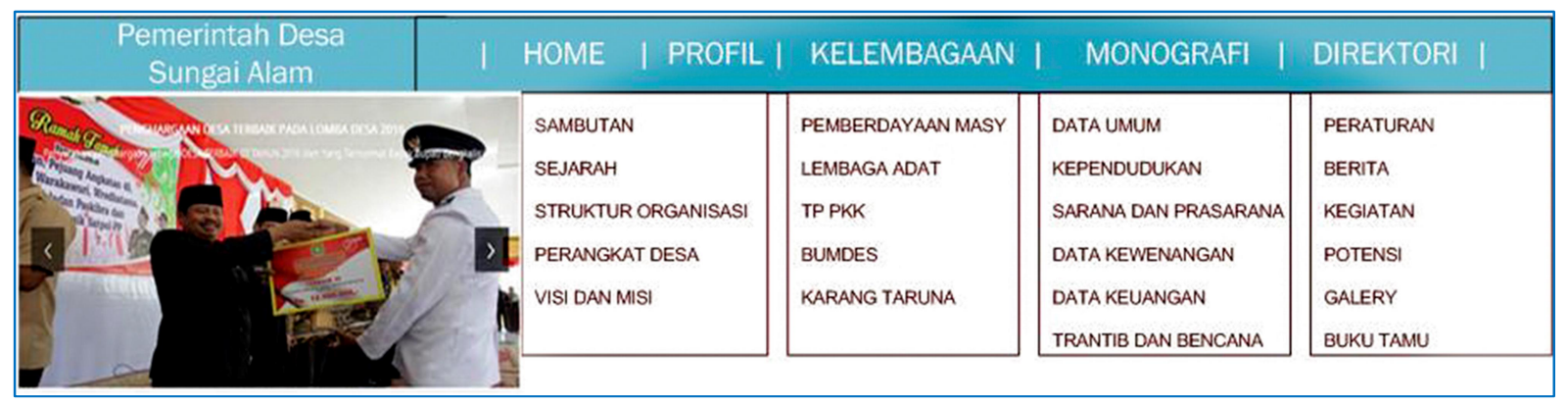

Gambar 10. Menu layanan informasi website desa

Gambar 11.Menunjukkansalah satu hasil dari proses data kependudukan yang disajikan dalam bentuk grafik. Grafik tersebut menjelaskan informasi tentang data kependudukan berdasarkan jenis kelamin, usia, tingkat pendidikan umum dan tingkat pendidikan khusus.

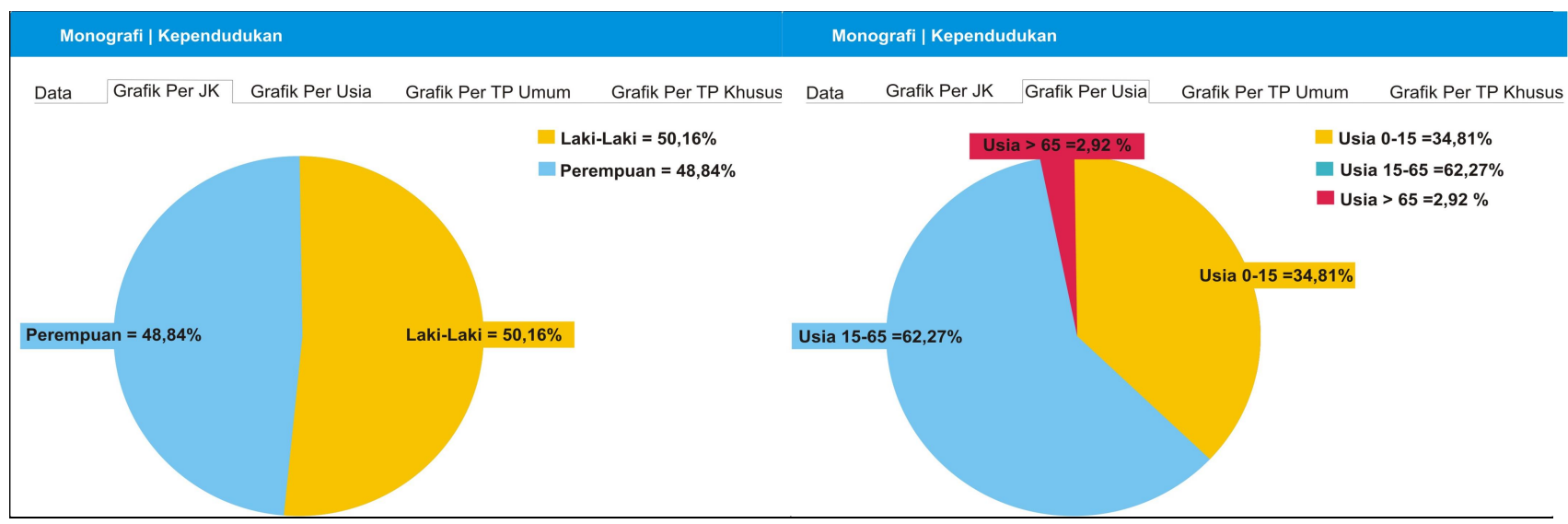

Gambar 11. Monografi kependudukan desa Sungai Alam.

\section{KESIMPULAN}

Sistem database terpadu dapat menampung semua informasi masing-masing desa. Pada database tersebut yang membedakan dengan database desa lain pada pengaturan pengguna database yang menyesuaikan dengan kebutuhan secara keseluruhan. Adapun bagian yang terlibat pada sistem database terpadu tersebut seperti operator desa, masyarakat dan pengelola database. Sistem database terpadu tersebut dapat membantu setiap desa untuk memiliki halaman website yang menampilkan informasi profile desa seperti sambutan, sejarah, struktur organisasi, perangkat desa, visi misi, informasi mengenai kelembagaan (pemberdayaan masyarakat, lembaga adat, PKK, Bumdes, dan karang taruna), informasi monografi (data umum, kependudukan, sarana prasarana, kewenangan, keuangan dan data bencana), informasi peraturan, berita, daftar kegiatan, potensi, galeri, buku tamu, dan informasi dalam bentuk grafik kepada masyarakat secara luas dalam rangka mewujudkan pemerintah desa yang transparan serta dapat mengotimalkan penyampaian informasi kepada pengguna secara efisien dan efektif. 


\section{REFERENSI}

[1] Connolly. T dan Begg. C., (2010), Database System A Practical Approuch to Design, Implementation, and mangement, Pearson.

[2] Garth R. B., Vichet H, Kenneth S. K., Michael O., Craig W.,Olga E., Igor T., Tatiana T., Kim D. P., Donna R. M., dan Terence D. M., 2014, Gene: a gene-centered information resource at NCBI, Nucleic Acids Research, Vol. 43, Database issue.

[3] Gil-Garcia, J.R, dan Pardo, T.A, 2005, E-Government success factors: Mapping practical tools to theoretical foundations, Geovernment Information Quarterly, 0740-624X.

[4] Kasmawi dan Mansur, 2016, Analisa dan Desain Sistem untuk Layanan Informasi Website Desa, SNIT 2016, ISSN : $2303-2790$.

[5] Luna B.R., Novak, M., Carr. H.M., Tinker. T,M., Black. A., Caselle. E.J., Hoban. M., Malone. D., dan Iles. A,. (2014), An Online Database for informing ecological network model, PLOS ONE, October 2014 Volume 9.

[6] Nurnawati, E.K., Ermawati, dan Ardyrusmaryya, D., 2016, Pemanfaatan basis data terintegrasi pada sistem informasi perangkat bergerak, Prosiding Seminar Nasional Aplikasi Sain \& Teknologi (SNAST), Yogyakarta. ISSN: 1979-911X

[7] Moody, L.D., (2003), Evaluating the Quality of Information Models: Empirical Testing of a Conseptual Model Quality Framework,IEEE. 0-76951877-X/03.

[8] Mohammad, Y, (2012), E-Learning Sebagai Media Pembelajaran Interaktif Berbasis Teknologi Informasi, Jurnal IImiah Faristek, Vol. 2 , No. 1.

[9] Muzid, S. dan Latifah, N., 2015, Pengembangan sistem layanan informasi desa (SILISA) terintegrasi berbasis SMS gateway, Prosiding SNATIF Ke - 2, ISBN: 978-602-1180-21-1.

[10] Sulistyowati, F., dan Dibyorin, C.R., 2013, Partisipasi warga terhadap sistem informasi desa, Jurnal Komunikasi ASPOKOM, Volume 2, Nomor 1, hlm. 579-587.

[11] Sukamto, Sulistyo, W., dan Suyanto, B., 2012, Sistem terpadu rekam medic rumah sakit dengan smart card, Jurnal Informatika Vol 6, No. 1.

[12] Thong, L.Y,J., dan Yap, S.C,. (1996), Information System Effectiviness : A User Statisfaction Approach, informaticm Processing \& Management, Vol. 32, No. 5, pp. 601-610.

[13] Pressman, R.S. (2002), Rekayasa Perangkat Lunak Pendekatan Praktisi (Buku Satu), Andi, Yogyakarta 